\title{
Analysis of the impact of harmful factors in the workplace on functioning of the respiratory system of firefighters
}

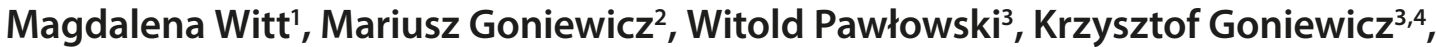 \\ Wiesława Biczysko 5 \\ ${ }^{1}$ Department of Rescue and Disaster Medicine, Poznan University of Medical Sciences, Poland \\ ${ }^{2}$ Medical University of Lublin, Department of Emergency Medicine, Poland \\ ${ }^{3}$ Medical University of Warsaw, Department of Disaster Medicine \\ ${ }^{4}$ Polish Air Force Academy, Faculty of National Security and Logistics \\ ${ }^{5}$ Department of Pathomorphology, Poznan University of Medical Sciences \\ Witt M, Goniewicz M, Pawłowski W, Goniewicz K, Biczysko W. Analysis of the impact of harmful factors in the workplace on functioning of \\ the respiratory system of firefighters. Ann Agric Environ Med. 2017; 24(3): 406-410. doi: 10.5604/12321966.1233561
}

\section{Abstract}

Introduction and objective. Firefighters are considered a healthy and fit group of individuals, well-prepared for taking action in disaster situations. While working, they suffer from exposure to certain toxic agents, especially combustion products generated when a fire takes place. Among them, the most frequent and the most toxic are: carbon monoxide, hydrogen cyanide, ammonia, and those resulting from PVC combustion - hydrochloride, phosgene and chloride. Additionally, fireextinguisher powder can be inhaled and lead to certain lesion in the airways. The aim of study was to ascertain the influence of toxic agents present at the scene of fire on the lung tissue of firefighters, and also to study this on an animal model.

Materials and methods. The study group consisted of firefighters who had a minimum of 10 years service. After completing a questionnaire, their clinical status was ascertained based on a general examination, laboratory tests and lung function tests.

Results. Questionnaire analysis showed a high percentage of pathological symptoms in the studied group. The incidence of the symptoms correlated with the duration of occupational exposure to toxic agents. Among other results, obstruction of flow in medium airways in about $30 \%$ of the studied individuals represented the most important finding. Experimental tests were next performed on male Wistar rats, aged 3 months. They were insufflated with the solution of powdered fire-extinguisher, after which morphology specimens of lung tissue were studied. Evidence for disseminated fibrosis was obtained, which supported the previous clinical findings in the firefighters.

Conclusion. The above shows correlation between occupational exposure and respiratory system involvement in firefighters. This justifies covering the group of firefighters with special medical care focused on prophilaxis, early detection and therapy of pulmonary diseases.

\section{Key words}

firefighters, occupational environment, respiratory system, biological test, pathomorphologiae

\section{INTRODUCTION}

For some time, the occupational group of firefighters has been the object of medical research, aimed at finding the relationship between occupational exposure and its effects on the fireman's body. It was found that the occupational exposure factors to which firefighters are exposed are primarily high temperatures, irritating, suffocating and toxic gases, vapours and dusts produced in the area of fire and extinguishing powder which, in addition to foam and water, is the third basic substance used by the fire brigade to extinguish fires. High temperature causes burns, both to the skin and the respiratory tract, and remaining in the area of the fire for a few minutes (2-5 min) can cause pathological changes in the upper and lower respiratory tract (especially the bronchial tubes), even in the absence of external damage to the skin [1].

The most important of harmful ingredients in the firefighters working environment is fire smoke. During the

Addres for correspondence: Mariusz Goniewicz, Medical University of Lublin, Department of Emergency Medicine, Poland

E-mail: mariusz.goniewicz@gmail.com

Received: 29 March 2014; accepted: 20 October 2014; first published: February 2017 past 20 years, a long list of toxic substances released during a fire has been created and their adverse effects on the human body. Next to carbon monoxide and carbon dioxide, the following are mentioned: hydrogen cyanide, ammonia, hydrogen chloride, phosgene, chlorine, halogen acids, and many others [2].

An additional element which determines the dangers of the firefighter's workplace are powder extinguishers. The dry chemical composition consists mainly of alkali metal bicarbonates, sulfates (especially potassium), orthophosphates and ammonium bisulfate, as well as silica and talc. Because of the fragmentation, the powder extinguishing agents have the ability to hang in the air in the form of dust for a long time. This dust, in people exposed to it, can easily penetrate into the respiratory system, causing irritation $[3,4]$.

Analyzing the acute impact which occupational exposure factors have on the respiratory tract of firefighters, inhalation injury is mentioned in the 4 first place. This phrase stands for changes in the respiratory tract, arising as a result of thermal and/or chemical injury associated with the inhalation of fire smoke. However, in cases of chronic, long-time exposure to the noxious agents discussed above, other problems may 
occur, such as the development of non-specific bronchial hyperreactivity, bronchiectasis, chronic obstructive pulmonary disease (COPD), asthma, occupational asthma or lung cancer $[5,6]$. COPD in patients who are particularly vulnerable, can lead to the development of pulmonary heart disease and severe heart failure. Silica and talc, also present in powder agent extinguishers, following many years of exposure can lead to the development of pneumoconiosis collagen: silicosis and talcosis $[3,4]$. The described changes are not only irreversible, but tend to spontaneously progress, even after the interruption of further exposure. Silica has been recognized by the International Agency for Research on Cancer as a probable carcinogen $[7,8]$.

\section{OBJECTIVE}

The aim of the study was to analyze the influence of harmful factors in the workplace of firefighters on the clinical and functional status of the respiratory system, and the morphological status of lung tissue of experimental animals.

\section{MATERIALS AND METHOD}

The first stage was conducted among the firefighter of the City Headquarters of the State Fire Service in Poznan, whose period of employment was a minimum 10 years, in a subjective examination of the survey type. The group comprised 160 men, of whom 119 were vocationally active and 41 were retired; 78 respondents (48.6\%) smoked, 51 (31.9\%) were former-smokers (i.e., those who in the course of the study did not smoke, but had smoked at least one cigarette a day or a pipe for a period of one year, based on the 'Questionnaire on respiratory symptoms' by MRC), and 31 (19.4\%) firefighters were non-smokers. The control group consisted of 80 men aged 28-84 years - 68 active and 12 retired professionals. Their vocation performed in Poznan was not associated with exposure to the risks specific to the study group of firefighters. Both groups were subjected to an examination using the 'Questionnaire on Respiratory Symptoms' by the Medical Research Council (MRC), personally modified.

During the next stage, the selected group who presented symptoms justifying the suspected presence of lesions within the respiratory system, underwent a physical examination and additional tests. 78 of them (including 6 who had retired) acceded. Additional tests performed on the respondents were: morphology of peripheral blood erythrocyte sedimentation rate (ESR), ECG and chest X-ray. A blood gas test of capillary blood arterialized from the fingertip was performed, as well as a functional examination covering the following parameters: FVC, $\mathrm{FEV}_{1}, \mathrm{FEV}_{1}$ \%, FVC, MVV, FEF, FMF. The results obtained were related to laboratory and studios standards and functional parameters to the predicted values for age, height and gender.

The resulting data were subjected to statistical analysis based on the Fisher and U-Gaussian tests, the hypotheses were tested at the significance level $\mathrm{p}<0.05$; the correlation coefficient for measurable parameters was calculated according to the Spearman method.

In parallel, the morphological lung tissue of experimental animals was evaluated, i.e. 90 male Wistar rats, aged 3 months, weighing $200 \pm 20 \mathrm{~g}$, underwent tracheal insufflation with a suspension of two powder extinguishing agents. The evaluation covered the powder extinguishing agents Pollenit F (LB3) and Totalit Super 80. Under general anesthesia, the agents were delivered to the exposed trachea in a single dose, suspended in $0.5 \mathrm{ml}$ of $0.9 \%$ saline solution, in an amount of dry chemicals: $50 \mathrm{mg}$ Pollenit F and $10 \mathrm{mg}$ of Totalit Super 80. After 1.5, 3 and 6 months of the experiment, the rats were sacrificed and the lungs were extracted for morphological studies. Control animals were analogously injected with $0.5 \mathrm{ml}$ of $0.9 \%$ aqueous saline solution. The sections of lung tissue were fixed in $10 \%$ neutral buffered formalin. The fixed material was embedded in paraffin and cut into sections with a thickness of 5 microns. Microscope images were assessed after staining with haematoxylin and eosin $(\mathrm{H}+\mathrm{E})$. Some of the material was fixed in Karnovsky's fixative and sunk into a mixture of Epon 812. Semi-thin sections, after staining with toluidine blue, were evaluated with an optical microscope.

\section{RESULTS}

Subjective test. Statistical analysis of the data obtained on the basis of the survey made it possible to determine a statistical relationship between the number of years of occupational exposure, the subjects' age and smoking, and symptoms of respiratory disease.

The next stage of the statistical analysis was to find statistically significant differences between the study group and the control, in the presence of symptoms that may indicate a developing disease process within the airways (Tab. 1).

Table 1. Occurrence of disease symptoms in the study and control groups

\begin{tabular}{lccc}
\hline Symptoms & $\begin{array}{c}\text { Study } \\
\text { group }\end{array}$ & $\begin{array}{c}\text { Control } \\
\text { group }\end{array}$ & $\begin{array}{c}\text { Significance } \\
\text { level }\end{array}$ \\
\hline Morning cough & $31.3 \%$ & $10.0 \%$ & $\mathrm{P}<0,0001$ \\
\hline Cough during the day or at night & $21.3 \%$ & $2.5 \%$ & $\mathrm{P}<0,0001$ \\
\hline Morning expectoration & $44.4 \%$ & $16.3 \%$ & $\mathrm{P}<0,0001$ \\
\hline Expectoration during the day or at night & $32.5 \%$ & $13.8 \%$ & $\mathrm{P}<0,002$ \\
\hline Shortness of breath & $56.3 \%$ & $20 \%$ & $\mathrm{P}<0.0001$ \\
\hline Paroxysmal dyspnea with wheezing & $25.0 \%$ & $2.5 \%$ & $\mathrm{P}<0,0001$ \\
\hline Night attacksbreathlessness & $17.5 \%$ & $1.3 \%$ & $\mathrm{P}<0,0001$ \\
\hline Symptoms of bronchial hyperreactivity & $38.3 \%$ & $15.0 \%$ & $\mathrm{P}<0,0001$ \\
\hline
\end{tabular}

Subjective and additional tests. In most cases, except for a few firefighters from the group of retirees, the physical examination did not produce any deviations from normality in terms of the respiratory and circulatory system. The results of a complete blood count and ESR were also located well within the normal laboratory range. At the same time, the blood gas test of arterialized capillary blood from the finger showed no exponents characteristic of respiratory failure among the study group. Analysis of the ECG of heart muscle did not demonstrate any significant deviations (in 93.6\% of cases the record was in the normal range), and $93.6 \%$ of patients showed no deviation from the normal condition in their chest radiographic image.

Analysis of the data obtained on the basis of the functional study was to assess the results in terms of belonging to the 
Table 2. Percentage distribution of functional parameters in the group of firefighters with regard to changes in the distribution of mild, moderate and severe deviations"

\begin{tabular}{|c|c|c|c|c|}
\hline Parameter & Standard & Mild deviation & $\begin{array}{l}\text { Moderate } \\
\text { deviation }\end{array}$ & $\begin{array}{c}\text { Severe } \\
\text { deviation }\end{array}$ \\
\hline FVC & $\begin{array}{c}76 \text { respondents } \\
(97.4 \%)\end{array}$ & - & - & $\begin{array}{c}2 \text { respondents } \\
(2.6 \%)\end{array}$ \\
\hline $\begin{array}{l}\text { FEV } 1 \% \\
\text { FVC }\end{array}$ & $\begin{array}{c}69 \text { respondents } \\
(88.5 \%)\end{array}$ & $\begin{array}{c}9 \text { respondents } \\
\quad(11.5 \%)\end{array}$ & - & - \\
\hline FEV1 & $\begin{array}{c}4 \text { respondents } \\
(94.9 \%)\end{array}$ & $\begin{array}{c}1 \text { respondent } \\
(1.3 \%)\end{array}$ & $\begin{array}{c}2 \text { respondents } \\
(2.6 \%)\end{array}$ & $\begin{array}{c}1 \text { respondent } \\
(1.3 \%)\end{array}$ \\
\hline MVV & $\begin{array}{c}74 \text { respondents } \\
(94.9 \%)\end{array}$ & $\begin{array}{c}1 \text { respondent } \\
(1.3 \%)\end{array}$ & $\begin{array}{c}2 \text { respondents } \\
(2.6 \%)\end{array}$ & $\begin{array}{c}1 \text { respondent } \\
(1.3 \%)\end{array}$ \\
\hline $\begin{array}{l}\text { FMF } \\
25-75 \%\end{array}$ & $\begin{array}{c}50 \text { respondents } \\
(64.1 \%)\end{array}$ & $\begin{array}{c}12 \text { respondents } \\
(15.4 \%)\end{array}$ & $\begin{array}{c}9 \text { respondents } \\
(11.5 \%)\end{array}$ & $\begin{array}{c}7 \text { respondents } \\
(9.0 \%)\end{array}$ \\
\hline
\end{tabular}

* - for FVC, FEV1, MVV, FMF, FEF obtained as a percentage of the predicted: a standard $100-80 \%$, mild deviation $79-70 \%$, moderate deviation $69-50 \%$, heavy $<50 \%$; for Tiffaneau expressed as $\%$ of FVCstandard $>70 \%$

Table 3. Disorders of airflow in airway of examined firefighters

\begin{tabular}{llcc}
\hline Spirometry & \multicolumn{3}{l}{ Flows in medium and small airways FMF 25-75\% } \\
\hline FVC, FEV1\% FVC, FEV1 & \multicolumn{1}{c}{ Reduced } & Standard \\
\hline \multirow{2}{*}{ Standard } & $\begin{array}{l}70 \text { respondents } \\
(89.7 \%)\end{array}$ & $\begin{array}{c}20 \text { respondents } \\
(25.6 \%)\end{array}$ & $\begin{array}{c}50 \text { respondents } \\
(64.1 \%)\end{array}$ \\
\hline \multirow{2}{*}{ Obstruction } & $\begin{array}{l}6 \text { respondents } \\
(7.7 \%)\end{array}$ & $\begin{array}{c}6 \text { respondents } \\
(7.7 \%)\end{array}$ & - \\
\hline \multirow{2}{*}{ Restriction } & 1 respondent & 1 respondent & - \\
& $1.3 \%$ & $1.3 \%$ & - \\
Mixed & 1 respondent & 1 respondent & - \\
\hline
\end{tabular}

range defined as normal, benign, moderate and severe. Also analyzed was the percentage distribution of functional parameters examined in the study group with regard to the individual compartments. The results of this analysis are shown in Table 2.

Results of the analysis of variations in the flow of air in the airways of respondents, tested with regard to changes of an obstructive, restrictive and mixed nature, and the quality of the flow in medium and small airways, is shown in Table 3.

Morphological tests. The results of the morphological evaluation of lung tissue of rats are as follows:

- there was an outbreak of fibrosis alternating with accompanying foci of emphysema;

- in large areas of the lung parenchyma, outside the foci of fibrosis, a small increase of stroma was found;

- exponents of variations in the thickness of vascular walls were visible (increase in arterial intimal cells), as well as the extension of the outline of lymphatic vessels, with accompanying endothelial cell proliferation;

- in the lung tissue from rats exposed to Pollenit F, more foci of fibrosis (single large clusters of fibrous connective tissue), emphysema, and red blood cell haemorrhaging fields were found.

\section{DISCUSSION}

Firefighting is a profession which has high health demands and whose representatives are perceived as healthy and very fit physically. Although the symptoms identified in firefighters during this survey may seem surprising, in the literature similar results were observed by Horsfield et al, Markowitz and others $[5,9,10]$. As for causes leading to the discussed pathology, in first place, environmental factors leading to the development of respiratory diseases should be noted. The first of these factors is cigarette smoking, which is the most important, the most common and best documented etiopathogenic factor $[11,12]$. Cigarette smoking causes inflammation in every smoker, but only $15-20 \%$ of this group reaches the development of obstructive changes [13]. Therefore, it cannot be justified that these results are caused solely through exposure to tobacco smoke. Support for this hypothesis may be found in a paper in which a group of non-smoking firefighters reported symptoms similar to those described above [14]. The second element of etiological disease processes in the respiratory tract is air pollution, both at home and at work [12]. It is believed that in addition to smoking, air pollution has a huge impact on the incidence of respiratory diseases, although the effect is much smaller (5-6 times) than the effect of cigarette smoking $[15,16]$. It appears that environmental exposure can affect the adverse effects cigarette smoke has and/or affect independently and act similarly to the above mentioned. Another factor is the place of work, which draws the attention of study authors, who confirm the presence of respiratory disease symptoms associated with occupational exposure in firefighters $[5,6]$. In terms of etiopathogenetic mechanisms responsible for the appearance of the symptoms discussed above, it must be taken into account that the overlap, spread over years of work, of small inhalation injuries, which at one time did not lead to acute changes, but may initiate or aggravate chronic pathological processes that will reveal themselves in the future $[17,18]$.

The second stage of the study pertained to clinical and laboratory tests in patients in whom a subjective test revealed the presence of symptoms such as cough, sputum, shortness of breath. The fact that the physical examination, with the exception of a few retired employees, showed no deviations in the respiratory or circulatory tracts seems to be justified. Firefighters are a occupational group subjected to annual mandatory periodic inspections. Any deviations in these regards are immediately detected, and the patients receive a diagnosis which, if it confirms disease processes, leads to the removal of the patient from further exposure to harmful factors. It seems that this is not contrary to the symptoms reported in the subjective study, because either they are not noticed by the interested parties and treated as 'normal' in smokers (e.g., cough, sputum production), or they are deliberately ignored or suppressed (e.g. shortness of breath) in fear of losing their job. The lack of significant deviations from the normal condition in the subjective test may indicate both their actual absence, as well as a stage of advancement of the disease, where it cannot be detected through a subjective test. It is known that both the subjective tests and routine physical tests have a low sensitivity of detection or exclusion of moderate obstructive changes [11].

The blood test results received in the next stage of the study, as well as a radiological examination of the chest and 
electrocardiogram of the heart, excluded the justification for the survey ascertained symptoms of cardiac or pulmonary disease, causing deviations in the afore-mentioned research. It is worth realizing that in the early stages of obstructive lung disease, both chest radiographic and electrocardiographic examination may not reveal any pathological changes [12].

The next stage of the research involved functional tests. The authors of many studies confirm a significant decline in the value of these parameters in the discussed occupational group, which is essential evidence of the adverse effects of the work environment of firefighters, visible especially among nonsmokers $[19,20]$. The results of the assessment of spirometric FVC, $\mathrm{FEV}_{1}, \mathrm{FEV}_{1} \%$, FVC (89.7\% standard) and MVV (94.9\% standard) did not demonstrate significant deviations in the group. On the other hand, the finding that $35.9 \%$ of respondents had flow disturbances within the medium-sized and small bronchi (FMF25 -75\%) may indicate the development of chronic obstructive changes. The decrease in exhaust flow is one of the earliest evidences of the presence of functional disorders occurring in patients with normal spirometry, even in the absence of clinical signs of the disease [21].

It should be assumed that no significant decrease in FEV, and FVC parameters can be associated with low precision capability to detect any ongoing disease processes in the small airways. This is particularly important given the fact that the obstructive changes may be a more serious consequence of inhalation trauma than is commonly believed, and that fact may have substantial long-term consequences, particularly in individuals with variations within the respiratory tract that were previously present [22]. Because in this occupational group at any stage, both during preliminary as well as periodic tests, a functional assessment is not performed, it is very likely that any disease processes that may develop within them will go unnoticed until the disease reaches an advanced stage, which may occur after reaching retirement age.

To complement the clinical observations, as well as the analysis of the impact factors of occupational exposure had on the study group, experimental studies on animals were performed. The presence of the exponents of sclerosis progressive fibrosis is an experimental confirmation of the presence of harmful factors in the work environment of firefighters. Very important from the point of assessing the impact of the environment on a professional living organism is the observation that the formation of fibrosis clumps in the preparations evaluated under microscope light, in which a definite advantage as to the occupied area is observed in collagen fibrils, seems to be a permanent change, not removed by cells of the immune system capable of collagenase and elastase. The pathology of chronic fibrotic lung parenchyma syndromes indicates that such changes are inherently progressive, despite the discontinuation of further exposure [4]. Also important is the observations that in pneumoconiosis, before a progressive massive fibrosis occurs, functional changes in the lungs are not observed; on the other hand, in patients with silicosis, without radiographic deviations, a decrease in $\mathrm{FEV}_{1}$ i FVC was found. This information may be particularly useful in the consideration of diagnostic possibilities in the analyzed group of employees. From data concerning the development of pneumoconiosis, it is known that a high prevalence of pneumoconiosis is recognized among pensioners and retirees, because the time needed for the development of pneumoconiosis changes is 15-20 years [23]. Since firefighters after 15 years of work experience can retire and not be subject to any further departmental examinations by the health service, this in conjunction with the above described data on the development of chronic obstructive changes as an effect of exposure to harmful factors, is of particular importance and should not remain unnoticed.

Analyzing the above-described parameters of environmental exposure involving firefighters, it must be assumed that the harmful factors present at their place of work have a significant impact on the respiratory system of the respondents. It seems that only such an approach which, on the one hand, takes into account and analyzes environmental factors, and on the other hand, provides ample opportunities for prevention, diagnosis and treatment of diseases of the respiratory tract in connection with occupational exposure, may be the basis of full-profile medical care of the occupational group of firefighters who are one of the leading departments standing guard round the clock over the life and health of citizens.

\section{CONCLUSIONS}

1. In the group of firefighters there was found a statistically higher presence than in the control group of symptoms in the respiratory system, and its relationship with both the number of years of occupational exposure and professional activity.

2. The presence of flow disturbances in the medium and small airways of firefighters and morphological changes in rats exposed to powder extinguishing agents, can attest to the emergence of disease processes in the respiratory tract in connection with occupational exposure.

3. At this stage of research it is difficult to assess the percentage of each pathogenetic component in discussed pathology in the analyzed occupational group.

4. It would be advisable to continue the extensive research on the working environment of firefighters and its impact on the living organism.

5. Particular care should be extended to those who in the study presented flow abnormalities in the bronchi, it would be appropriate on the one hand to provide them with frequent periodic monitoring of their health status, and on the other, to attempt to assess the flows in their small airways using modern diagnostic methods.

\section{REFERENCES}

1. Krzywiecki A. Uszkodzenie tkanki płucnej wywołane oparzeniem termicznym. In: Płusa T, editor. Stany zagrożenia życia w pneumonologii i alergologii. Sanmedia, Warszawa 1993. p. 158-163.

2. Hartzell G, Packham S, et al. Toxic products from fire. Am Ind Hig Assoc. 1983; 44:248-255.

3. Enders P. Pylice i chemiczne uszkodzenia płuc. In: Enders P, editor. Pneumonologia praktyczna. Via Medica, Gdańsk 1995. p. 167-178.

4. Marek K. Choroby zawodowe układu oddechowego. In: Orłowski W, editor. Nauka o chorobach wewnętrznych. Vol. V. PZWL, Warszawa 1990. p. 281-289.

5. Horsfield K, Cooper FM, et al. Respiratory symptoms in West Sussex firemen. Brit J Ind Med. 1988; 45:251-255.

6. Wright J, Cagle P, et al. Diseases of the small airways. Am Rev Respir Dis. 1992; 146:240-264.

7. Hardy TS, Weill H. Crystalline silica: risks and policy. Environ Health Perspect. 1995; 103:152-155. 
8. Pairon JC, Brochard P, et al. Silica and lung cancer: a controversial issue. Eur Resp J. 1991; 4:730-744.

9. Alberg AJ, Samet JM. Epidemiology of lung cancer. Chest Journal 2003; 123(1_suppl): 21S-49S.

10. Large AA, Owens GR, et al. The short-term effects of smoke exposure on the pulmonary function of firefighters. Chest, 1990; 97:806-809.

11. Siafakas NM, Vermeire P, et al. Optymalne postępowanie diagnostyczne i leczenie przewlekłej obturacyjnej choroby płuc. Medycyna Praktyczna, 1996; 6:7-40.

12. Śliwiński P. Przewlekła obturacyjna choroba płuc. Nowa Medycyna. 1996; 11:23-27.

13. Pierzchała W, Barczyk A. Postępowanie w przewlekłej obturacyjnej chorobie płuc. The European Respiratory Society Statement 1995 and The American Thoracic Society Statement 1995.

14. Sparrow D, Bosse R, et al. The effect of occupational exposure on pulmonary function. A longitudinal evaluation of firefighters and nonfirefighters. Am Rev Resp Dis. 1982; 125:319-322.

15. Niepsuj G, Pudelski J. Przewlekłe zapalenie oskrzeli i sprawność wentylacyjna płuc z uwzględnieniem czynności drobnych dróg oddechowych u pracowników Zakładów Koksochemicznych w Zabrzu. Pneumonol Alergol Pol. 1992; 60:61-65.

16. Pudelski J. Wpływ środowiska na układ oddechowy. Pneumonol Pol. 1984; LII:11-12.

17. Tornling G, Gustavsson P, et al. Mortality and cancer incidence in Stockholm firefighters. Am J Ind Med. 1994; 25:219-228.

18. Young I, Jackson J, et al. Chronic respiratory disease and respiratory function in a group of firefighters. Med J Aust. 1980; 1:654-658.

19. Chia K, Phoon WO, et al. Transit time analysis of the forced expiratory spirogram of firefighters. Ann Acad Med Singapore. 1997; 16:324-327.

20. Kales S, Polyhronopoulos GN, et al. Medical surveillance of hazardous materials response firefighters: a two- year prospective study. J Em Med. 1997; 39:238-247.

21. Górecka D, Śliwiński P, et al. Przewlekła obturacyjna choroba płuc. Studio sense, Warszawa 1995.

22. Cooke N, Cobley J, et al. Airflow obstruction after smoke inhalation. Anesthesia. 1982; 37:830-832.

23. Gołębiewski S. Choroby zawodowe układu oddechowego. In: RowińskaZakrzewska E, Niemirowska H, editors. Gruźlica i choroby płuc. PZWL, Warszawa 1985. p. 154-160. 